\title{
Factors Affecting Market Outlet Choice of Kocho Producers in Cheha District, Gurage Zone, Southern Ethiopia
}

\author{
Henok Tesfaye ${ }^{1} \quad$ Lemma Zemedu $^{2} \quad$ Alelign Ademe ${ }^{2}$ \\ 1.Department of Agribusiness and Value Chain Management, Wolkite University, Wolkite, Ethiopia P O box \\ 07, Wolkite, Ethiopia \\ 2.Department of Agricultural Economics, Haramaya University, Haramaya, Ethiopia \\ P O box 138, Diredawa, Ethiopia
}

\begin{abstract}
Cheha district in Gurage Zone of Southern Ethiopia is known for Enset farming. However, use of traditional technologies and poor linkages along the market chain were mentioned the major problems constraining the potential benefits from the sector. Therefore, this study was aimed at analyzing Factors Affecting Market Outlet Choice of Kocho. The data were collected from both primary and secondary sources. The primary data for this study were collected from 140 randomly selected farmers. Two-stage sampling was employed to draw sample of enset farmers. Multivariate probit models were used to identify Factors Affecting Market Outlet Choice of Kocho producers and the result revealed that that the likelihood of households to use collectors, wholesalers, retailers, consumers and processors market outlet for Kocho were 41\%, 38.5\%, 65.1\%, 53.6\% and 23.5\%. The multivariate probit model results also indicated that ownership of transport facility, Kocho quantity produced, perception toward current price, Extension service, distance from the nearest market and value addition of Kocho were significantly influenced Enset producers choices of Kocho market outlets. Providing timely and adequate modern production inputs to improve quantity produced, strengthening extension services to provide adequate information, and developing and improving infrastructures are recommended by study to enhance farmers' choice of suitable market outlets.
\end{abstract}

Keywords; Value chain, Enset, Multiple regression model, Multivariate probit model, Market outlet, Value addition, Cheha.

DOI: $10.7176 / \mathrm{DCS} / 9-3-01$

Publication date:March $31^{\text {st }} 2019$

\section{INTRODUCTION}

\subsection{Background of the Study}

Enset is an herbaceous plant, indigenous of Ethiopia, closely related to the family of the banana tree from the morphological point of view but completely different in terms of usage, life cycle and development (Shigeta, 1991, Steven et al. 1997). It is cultivated from mid-altitude to the highlands of the south, southwest and central regions of Ethiopia. More than 15 million people in the Southern Nation Nationalities and Peoples Region depend upon Enset for human food, fiber, animal forage, construction materials and medicines (Tesfaye, 2013).

Moreover, it has multipurpose uses, and nothing will be left from the plant. The major foods obtained from Enset are Kocho, Bulla and Amicho. Kocho is the bulk of the fermented starch obtained from the mixture of decorticated (scraped) leaf sheaths and grated corm (underground stem base). Bulla is the small water-soluble starchy product that may be separated from Kocho during processing by squeezing and decanting the liquid. Amicho is the fleshly inner portion of the Enset corm, which may be cooked and eaten separately, tasting similar to potato (Ayalew, 2006).

According to CSA (2017) report, 123,479,334.00 Enset plants were harvested in the country in 2017 and produced 31,625,631.77 quintals of Kocho, 1,100,606.24 quintals of Bulla and 28,009,778.70 quintals of Amicho. Although, Gurage zone had largest share with 4,011,142-harvested Enset population and produced 1,247,820.99 quintals of Kocho, 64,128.91 quintals of Bulla and 1,199,961.12 quintals of Amicho produced in 2017. Moreover, According to Cheha district office of agriculture and natural resource report (2017), the district has the second largest Enset area coverage in the zone next to Enemor District with 5,700 hectare out of 40,190 hectare of total cultivated land. In addition, 101,388 quintals of Kocho, 11,440 quintals of Bulla and 85,240 quintals of Amicho were produced in the study area in 2017. Kocho and Bulla were supplied to local, Zonal, and central markets. However, Amicho is not possible to deliver it to markets that are located far from the production points, due to its perishable nature (Ashenafi et al., 2017).

Enset crop production for market requires reorientation of the production system and development of a knowledge based and responsive organizational support. Promoting farmer organization; provision of training on value addition, Enset crop products hygiene, market information seeking, developing infrastructure, providing incentives and promoting integrated with supply and processing and marketing sectors, promoting participatory methods in research and technology development, and supporting pro-poor research and advisory services are vital to empower Smallholder Enset farmers (Tsedale, 2009). 
Farmers in Ethiopia in general and in SNNPRS region in particular affected by low producer's price, on one hand, and high consumer's price, on the other hand. Major reasons for this is lack of proper transport facilities and other infrastructure services, inadequate capital facilities, high handling costs, inadequate market information system, weak bargaining power of farmers and underdeveloped industrial sectors (Jema, 2008).

Enset products are important sources of food and income, its production is crucial in Ethiopia. However, this huge potential of production has not fully exploited and promoted in the country. Poor marketing infrastructure, use of traditional technologies, limited supply, and lack of marketing support services and market information contribute to under exploitation of Enset production potential (Steven et al., 1997). In addition, land shortage, recurrent drought, disease, lack of improved clones in terms of yield and disease resistance; labor shortage, lack of improved processing and storage technologies, improper or traditional agronomic practice, financial shortage and long time maturity are the major challenge in Enset production (Abrham et al., 2012). Moreover, poor collaboration among and between value chain actors, inefficient Enset marketing characterized by high margins and poor marketing facilities and services is considered to be a major constraint Enset product marketing (Ashenafi et al., 2017).

In the past, most of interventions to develop Enset farm focused more on increasing production, especially the so-called high potential areas and with less attention to marketing system. However, the development of improved marketing system and linkages among actors are pivotal to increase production (Abebe and Paul, 2015). Production, processing, marketing and consumption activities are not coordinated to create competitiveness and efficiency. Existing scenario indicates that Enset value chain actors do not get opportunities to talk to each other about issues affecting the entire value chain (Nuri, 2016). As a result, information asymmetry in markets is pervasive and farmers may not be able to co-evolve with changing market conditions. Although, modern markets that give emphasis to quality and safety are believe to replace traditional markets and reduce market outlets for Enset farmers.

Kocho is produced and supplied for different market channels and local collector, wholesaler, processors, retailer and consumer market outlets are outlets for which producers supply the product in the study area. In spite of different challenges for outlet choices of the producers; they can select one or more channels among the existing market channels in order to maximize expected utility thereby making a joint decision regarding with the existing constraints of market channel choice and how to get expected further outcomes. Although farmers sale Kocho through different market outlets however no empirical evidences has been done on factors affecting market outlet choice of Kocho producers in Cheha district. So, results of this study is very crucial in terms of providing very important information on the choice of appropriate market outlets through analyzing determinants of Kocho producer channel choice decisions thereby enable them to get reasonable profit in Cheha district.

\section{RESEARCH METHOD}

\subsection{Description of the Study Area}

This study was undertaken in Cheha district of Gurage Zone, Southern Nations, Nationalities and Peoples Regional State (SNNPRS), Ethiopia (Figure 2). The capital of the district is Emdbir, which is located at $188 \mathrm{~km}$ south of Addis Ababa on the way to Wolkite town, the capital of the Zone. The geographical location of the district extends from $8^{\circ} 00^{\prime} 18.9^{\prime \prime}$ to $8^{\circ} 15^{\prime} 28.53^{\prime \prime} \mathrm{N}$ and $37^{\circ} 35^{\prime} 46.48^{\prime \prime}$ to $38^{\circ} 03^{\prime} 59.59^{\prime \prime} \mathrm{E}$ at an elevation ranging from 1,900 to 3,000 meters above sea level (masl). It has a total population of 115,918 and has a total area of 57,313.85 ha of which 40,190 ha is cultivated. The district constitutes 39 rural Kebeles. As it was true to the other parts of Ethiopia, rainfall and temperature conditions depend on elevation. The average annual rainfall of the area is about 1268.04 $\mathrm{mm}$ and the average maximum and minimum temperature in the study area is $24.97^{\circ} \mathrm{C}$ and $10.69^{\circ} \mathrm{C}$, respectively.

The major cereal crops produced in the woreda include teff, maize, different fruits and vegetable crops. Farmers of the woreda also widely produce Enset for different purposes like for for food in the form of Kocho, Bulla, and Amicho and for medical purpose. The leaves are also used for different purposes like fed for cattle and cooking of bread. The rearing and cultivation of cattle and Enset are mutually interdependent since manure is continuously applied to the Enset and the cattle are fed on Enset leaves (CDOAN, 2017). 


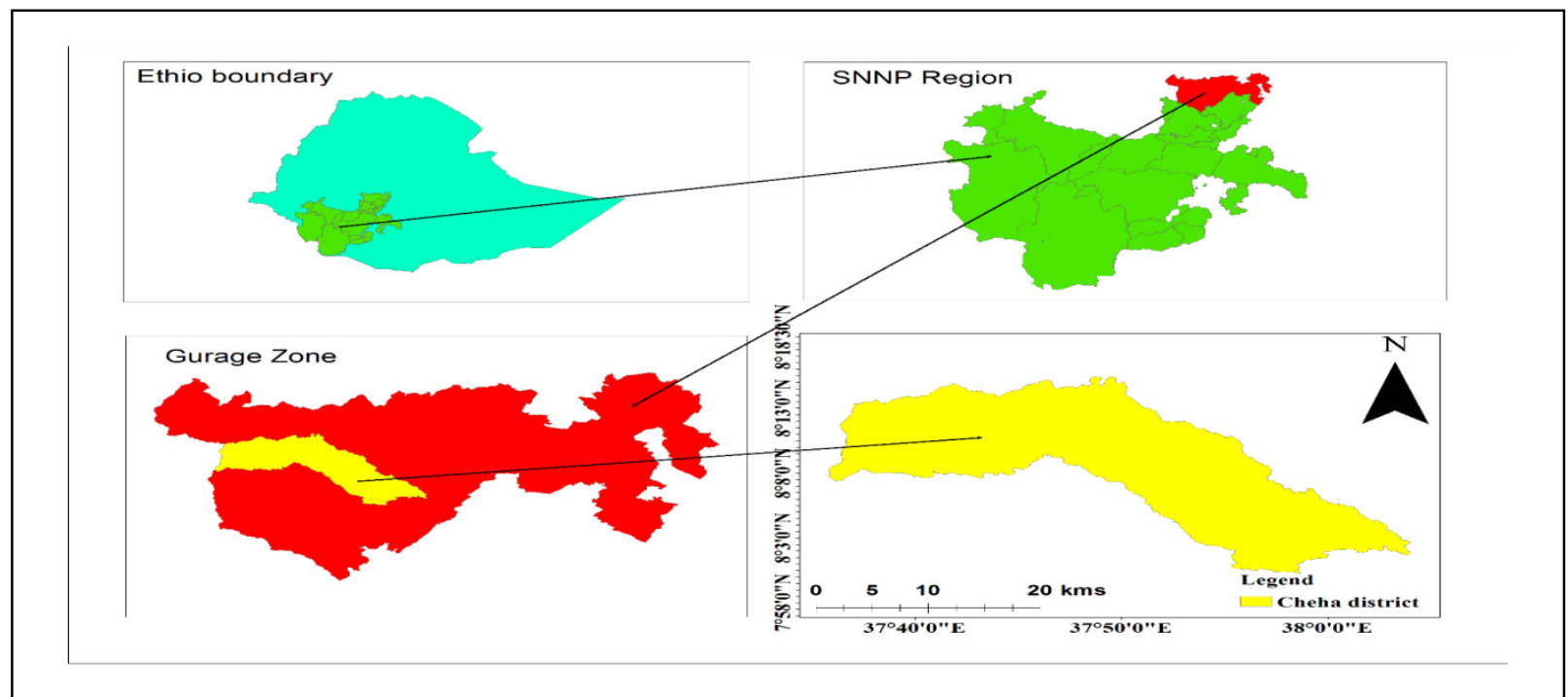

Figure 1. Maps of the study area (Ethio GIS)

\subsection{Sources and Method of Data Collection}

Both primary and secondary data were used for this study. To collect primary data, formal and informal sample survey methods were used. Primary data sources were Enset farmers (i.e. member of household who is responsible for Enset production and management). Formal survey was undertaken from farmers using a pre-tested structured interview schedules. Informal survey was conducted from key informant interview with relevant experts and other officials for additional information and/or crosschecking the data. Both qualitative and quantitative data were collected and used for the study.

Secondary data was gathered from published and unpublished materials, zonal and District agricultural marketing offices, town Office of Trade and Industry (OoTI), books, Central Statistics agency (CSA) and from different development organizations of the study area.

\subsection{Sampling Procedure and Sample Size Determination}

In order to select a representative sample, two stage sampling was employed. In the first stage, 6 kebeles were selected randomly from 39 kebeles found in Cheha district. Then in the second stage, 140 sample Enset farmers were selected randomly based on probability proportional to the population size of the selected kebeles (Table 1). Following Yemane (1967), the sample size is determined by the formula:

$n=\frac{N}{1+N(e)^{2}}=\frac{24,318}{1+24,318(0.085)^{2}} \sim 140$

Where, $\mathrm{n}=$ the minimum number of sample size, $\mathrm{N}=$ the total number of Enset growing households in the study area, $\mathrm{e}=$ level of precision or the tolerable error in the sample.

Table 1: Total number of Enset producers and sample Enset producers

\begin{tabular}{llll}
\hline Name of selected kebeles & $\begin{array}{l}\text { Number of households participating in } \\
\text { production. }\end{array}$ & $\begin{array}{l}\text { Enset } \\
\text { Enset } \\
\text { producers farmers }\end{array}$ \\
\hline Yefersye & 736 & & 21 \\
Girardibir & 806 & & 23 \\
Ager & 946 & & 27 \\
Yewezhi & 561 & & 16 \\
Yefekterekwedero & 701 & & 20 \\
Yefikterekindebera & 1120 & 33 \\
\hline
\end{tabular}

Source: Cheha District Agricultural offices, 2017

\subsection{Method of Data Analysis}

Descriptive and inferential statistical tools such as frequencies, percentages, mean, and standard deviations were used in the process of describing socioeconomic and demographic characteristics of Enset farmers, chain actors and Enset crop products marketing functions, facilities and services.

Econometric analysis uses multivariate probit (MVP). Some empirical studies on market outlet choice assume that the addition or deletion of alternative outcome categories does not affect the odds among the remaining outcomes and the odds of choosing a particular market outlet over the other do not depend on which other outcomes are possibly chosen. But in the study area there are several market outlets (local collectors, wholesalers, retailers, 
processors and consumers) and farmers have the possibility to select more outlets simultaneously to maximize the expected utility and due to this there is some overlapping and many farmers sell to more than one market outlet. Multivariate probit approach simultaneously models the influence of the set of explanatory variables on choice of market channels, while allowing for the potential correlations between unobserved disturbances, as well as the relationships between the choices of different market channels (Belderbos et al., 2004). So, using multinomial logit model for outlet choice is not viable due to market channel choice might not mutually be exclusive; considering the possibility of simultaneous choices of channel and the potential correlations among these market channel choice decisions. Multivariate probit model is preferred over the multinomial logit model because of the independence of irrelevant alternatives (IIA) assumption and the relative risk of choosing one outlet can be affected by the relative risk of the choosing the other (Greene, 2003).

The multivariate probit econometric approach for this study is characterized by a set of $\mathrm{m}$ binary dependent variables $Y_{i j}$ such that:

$Y_{i j}^{*}=\beta_{j} X_{i}+\varepsilon_{i} \quad(j=1,2,3,4,5 \ldots m)$

Using the indicator function, the unobserved preferences in equation (5) translates into the observed binary outcome equation for each choice as follows:

$Y_{i j}^{*}=\left\{\begin{array}{c}Y i=1 \text { if } Y_{i j}^{*}>0 \\ 0 \text { otherwise. }\end{array} \quad(j=1,2,3,4,5 \ldots m)\right.$

Where $j=1,2,3,4,5 \ldots \mathrm{m}$ denotes the the market outlet choice; $\mathrm{x}_{\mathrm{i}}$ is a vector of explanatory variables, $\beta_{j}$ denotes the vector of parameter to be estimated, and $\varepsilon_{\mathrm{i}}$ are random error terms distributed as multivariate normal distribution with zero mean and unitary variance.

\subsection{Definition of Variables and Hypothesis}

Marketing outlet choice: It is categorical variable measured by the choice of selling Kocho to different traders. The outlet choices might be along farmers decision involving in alternative markets. Enset crop farmer has unordered market outlet choices assuming collectors, wholesalers, retailers, processors and consumers. It represented in the model as $\rho 1$ for those households who choose to sell Enset product to collectors, $\rho 2$ for households who choose wholesalers, $\rho 3$ for households who choose retailers, $\rho 4$ for households who choose consumers outlets and $\rho 5$ for households who choose processors to sell Kocho.

Table 2. Independent variables for factors affecting market outlet choices

\begin{tabular}{llll}
\hline No & & Types & Marketing outlet choice \\
\hline 1 & Family size(HHSZ) & Continuous & $-/+$ \\
2 & Experience (EXPERI) & Continuous & $-/+$ \\
3 & Education level (YEARSCH) & Continuous & $-/+$ \\
4 & Dependency ratio (DEPR) & Continuous & $-/+$ \\
5 & Distance to nearest market (DNM) & Continuous & $-/+$ \\
6 & Livestock owned (LIOW) & Continuous & $-/+$ \\
7 & Ownership of transport (TRAO) & Dummy & $-/+$ \\
8 & Quantity supplied (K/BOUTPUT) & Continuous & $-/+$ \\
9 & Access to credit (ACC) & Dummy & $-/+$ \\
10 & Extension service(EXT) & Continuous & $-/+$ \\
11 & Value addition on Kocho (VAKG) & Dummy & $-/+$ \\
12 & Perception of current price (PCUPRKO) & Dummy & $-/+$ \\
13 & Non/off-farm activity (INFNDS) & Continuous & $-/+$ \\
\hline
\end{tabular}

\section{RESULTS AND DISCUSSION}

\subsection{Demographic and socioeconomic characteristics of sampled households}

The number of sample respondents handled during the survey was 140. All respondents were female, who take the responsibility of both Enset production and marketing in the household, the average family size of sample households was 4.13 with the minimum and maximum of 2.6 and 7.5 in adult equivalent respectively (Table 3 ). Moreover, sample households were also characterized by the presence of large number of dependents with mean dependency ratio of 0.83 , implying that every 100 person within the economically active population groups supported not only themselves but also additional 83 dependent persons with different necessities. That implies shortage of active household labor force to undertake various agricultural operations.

The mean age of the respondent person of the households was 40, indicating that the responsible person for production and marketing of Enset in the household has good experience. As age is considered as a crucial factor since, it determines whether the household benefits from the experience of an older person or has to base its decisions on the risk-taking attitudes of younger farmers. Educational level also considered to contribute positively to Enset production and marketing. The average educational level of respondents was 3.43 in year of schooling with minimum of zero and maximum of 12. 
Table 1: Demographics and socioeconomic characteristics of sampled farmer

\begin{tabular}{lllll}
\hline Variable & Mean & Minimum & Maximum & Standard deviation \\
\hline Age & 40.37 & 28 & 55 & 6.57 \\
Family size & 4.134 & 2.6 & 7.5 & 1.43 \\
Dependency ratio & 0.835 & 0 & 3 & 0.67 \\
Educational level & 3.43 & 0 & 12 & 3.09 \\
Experience & 21 & 8 & 31 & 5.60 \\
\hline
\end{tabular}

Source: Own computation from survey data $(\mathrm{N}=140)$

In this study, experience in production of Enset were also considered since, farm experience in general; farming experience in Enset production in particular is considered to positively contribute to production and marketing of Enset from accumulated knowledge and skill. The results depicts that the average farming experiences of respondents for Enset were about 21 years with standard deviation of 5.60. This shows family member who is responsible for Enset production and marketing have a good experience.

\subsection{Institutional factors}

Extension contact: Extension service in Cheha District is fully provided by district agricultural departments. Even though three development agents institutionally assigned to work in crop production, animal science and natural resources, the service is hardly imparted on Enset product to influence production task. The result further highlighted that, learning and knowledge imparting has failed to support households to participate in the market chain (key informants). As the data explained, mean frequency of visit by development agent is 15.1 per year (Table 4).

Access to credit: The availability of financial sources like credit is crucial for farmers. Some farmers are using as an important input for agricultural activities. Table 4 shows that $57.1 \%$ of respondents have access to credit. However, only $13.6 \%$ of the respondents had taken credit from the available sources in the study area. The credit sources for these farmers were local moneylenders and microfinance. However, the credit provision is based on group collateral but farmers are not much interested in this approach in order not to pay for defaulters in their group. In addition, there is no credit for production and marketing of Enset products.

Distance from the nearest market: It is important for farmer to participate in marketing of agricultural product and participation in value addition. The Table below shows the average distance of farmer households to the nearest market is $2.93 \mathrm{~km}$ with a minimum of 1.5 to maximum of $5 \mathrm{~km}$.

\subsection{Resource ownership and other income generating activities}

Livestock: It is the farmer's most important source of income, food, draught or traction power for cultivation of land and manure for Enset production. To assess the livestock holding of each household, the Tropical Livestock unit (TLU) per household was calculated. The result depicted that the TLU of sample households ranged from 3 to 7.82. The average livestock holding of Enset producing farmers in the study area was 5.78 TLU with standard deviation of 0.92 .

Ownership of transport facilities: The majority of the respondents have transportation facility. $64.5 \%$ of the respondents have their own transportation facility. The rest $35.5 \%$ of the respondents reported that they do not have any form of own transportation facility. However, none of the respondents has any form truck transportation access.

Non/off-farm activities: As the survey data indicated that, above 65\% respondent household have other income generating activity other than farming (non/off farm activity). Other income source may help farmer to fulfill value adding equipment's, and better access to market information information.

\subsection{Enset production and average Kocho supplied}

The results presented in Table 5 depicted that on average a farmer household allocated 0.43 ha for Enset. On average, a farmer household sale 212 kilogram of Kocho out of a produced quantity of 550 kilogram.

Table 5: Enset production and marketing

\begin{tabular}{lllll}
\hline Variable & Mean & Minimum & Maximum & Standard deviation \\
\hline Land allocated for Enset (Hectare) & 0.433 & 0.125 & 1 & 0.27 \\
Kocho quantity produced (Kilogram) & 550.14 & 160 & 1400 & 361.23 \\
Kocho quantity sold (Kilogram) & 212.14 & 35 & 600 & 171.90 \\
\hline
\end{tabular}

Source: Own computation from survey data $(\mathrm{N}=140)$. 


\subsection{Factors affecting Kocho producers market outlet choices}

Multivariate probit model was used to identify factors affecting Kocho market outlet choice decision of the farm households. Wald test $\left(\chi^{2}(65)=137.84, p=0.000\right)$ is significant at $1 \%$ probability level. This result implies that the coefficients are jointly significant and the explanatory power of the factors included in the model is satisfactory. Furthermore, results of likelihood ratio test of the model $\left(\operatorname{LR} \chi^{2}(10)=51.232, \chi^{2}=0.000\right)$ is statistically significant at $1 \%$ significance level, indicating that the independence of the disturbance terms (independence of market outlet choice) is rejected and there are significant joint correlations for two estimated coefficients across the equations in the models. The correlation coefficients are statistically different from zero in 5 of the 10 cases, confirming the appropriateness of the multivariate probit specification and market choice outlets are not mutually independent. The results on correlation coefficients of the error terms indicate that there is complementarities (positive correlation) and substitutability (negative correlation) between different market outlet choices being used by farmers. The SML estimation results suggested that there was positive and significant interdependence between household decisions to choose consumer and processors outlet (Rho45). The SML estimation results also suggested that there is negative and significant interdependence between household decisions to choose collectors outlet and wholesalers outlet $\left(\mathrm{Rho}_{12}\right)$; wholesalers outlet and retailers outlet $\left(\mathrm{Rho}_{23}\right)$; retailer outlet and consumer outlet $\left(\mathrm{Rho}_{34}\right)$ and processor outlet and retailers outlet $\left(\mathrm{Rho}_{35}\right)$ (Table 6).

The result of multivariate probit model shows that the likelihood of households to use collectors, wholesalers, retailers, consumers and processors market outlet for Kocho were 41\%, 38.5\%, 65.1\%, 53.6\% and 23.5\%, respectively. The result also shows that the joint probability of using all outlet choice was only $0.112 \%$ and the joint probability of failure to use all outlets was $0.456 \%$. As depicted in Table 6 out of thirty explanatory variables included in multivariate probit model, two variables significantly affected collectors market outlet; three variables significantly affected wholesaler market outlet; three variables significantly affected retailer outlet; two variables significantly affected consumer outlet; and two variables significantly affected processors outlet choice at 1, 5 and $10 \%$ probability levels.

Distance from the nearest market: The result show that, this variable has negative and significant effect on the likelihood of choosing processors as an outlet of household at 1\% significant level. This implies that farmers far from nearest market are less likely to sell Kocho to processors. This might be due to the fact that most producers prefer to sell their products without incurring transaction costs. Moreover, distance affects access to market information and contact with processors. This result is in line with Berhanu et al. (2013) who confirmed that distance to nearest urban center negatively affected accessing hotel or restaurant milk market.

Family size: The likelihood of choosing retailers market outlet was negatively and significantly affected by family size at 5\% significant level. This result shows that farmers having more family size would less likely sell Kocho to retailers compared to those household who had less family size. The possible reason might be as household size increase consumption level increase, which in turn decrease quantity supply. Therefore, as the quantity supplied is small, they would not prefer retailer outlets rather they will prefer collector or consumers.

Table 6: Multivariate probit results of the determinants of Kocho market outlet choice

\begin{tabular}{|c|c|c|c|c|c|c|c|c|c|c|}
\hline \multirow{2}{*}{ Variables } & \multicolumn{2}{|c|}{ Collectors } & \multicolumn{2}{|c|}{ Wholesalers } & \multicolumn{2}{|l|}{ Retailers } & \multicolumn{2}{|l|}{ Consumers } & \multicolumn{2}{|c|}{ Processors/h\&r } \\
\hline & Coef. & Std. Err. & Coef. & Std. Err. & Coef. & Std. Err. & Coef. & Std. Err. & Coef. & Std. Err. \\
\hline Experience & -0.006 & 0.042 & 0.023 & 0.027 & 0.012 & 0.027 & -0.042 & 0.029 & -0.024 & 0.032 \\
\hline Distance to nearest market & -0.039 & 0.382 & -0.129 & 0.232 & -0.145 & 0.222 & -0.010 & 0.231 & $-0.55 * * *$ & 0.296 \\
\hline Family size & -0.123 & 0.139 & 0.065 & 0.086 & $-0.203 * *$ & 0.086 & 0.086 & 0.088 & 0.1237 & 0.098 \\
\hline Depen & -0.055 & 43 & -0.011 & 0.200 & 0.057 & 0.200 & -0.154 & 0.205 & 0.1455 & 0.229 \\
\hline Educa & -0.058 & 0.068 & -0.015 & 0.044 & -0.045 & 0.043 & 0.033 & 0.044 & -0.000 & 0.049 \\
\hline Liv & -0.268 & 0 & 0.067 & 0 & -0.1 & 0.137 & 0.094 & 44 & -0.134 & 0.156 \\
\hline Owne & $-1.129 *$ & 0.596 & $0.922 * *$ & 0.409 & -0.571 & 0.419 & 0.487 & 0.417 & 0.365 & 0.529 \\
\hline Kocho Quantity supplied & -0.0006 & 0.001 & $0.003 * * *$ & 0.001 & 0.0005 & 0.0007 & $-0.0014 * *$ & 0.0007 & 0.0009 & 0.001 \\
\hline Access to credit & 0.095 & 0.407 & 0.108 & 0.256 & -0.127 & 0.254 & -0.053 & 0.259 & -0.295 & 0.292 \\
\hline Extension service & 0.182 & 0.421 & -0.193 & 0.277 & $-0.508^{*}$ & 0.278 & 0.355 & 0.282 & 0.211 & 0.317 \\
\hline VA per KG of Kocho & $-1.40 * * *$ & 0.414 & -0.114 & 0.217 & $-0.398^{*}$ & 0.220 & $0.626 * * *$ & 0.240 & $0.524 *$ & 0.275 \\
\hline Perception of current pric & 0.194 & 1.020 & $1.270 * *$ & 0.583 & -0.590 & 0.536 & 0.160 & 0.485 & 0.620 & 0.515 \\
\hline Non/off-farm activity & -0.49 & 0.653 & -0.006 & 0.438 & -0.395 & 0.447 & 0.194 & 0.487 & 0.264 & 0.531 \\
\hline Cons & $10.37 * * *$ & 3.28 & -1.63 & 1.76 & $6.309 * * *$ & 1.826 & $-3.764 * *$ & 1.849 & -2.369 & 2.021 \\
\hline
\end{tabular}




\begin{tabular}{|c|c|c|c|c|c|}
\hline & Collectors & Wholesalers & Retailers & Consumer & Processors \\
\hline Rho2 & $-0.297 *$ & & & & \\
\hline Rho3 & 0.245 & $-0.510 * * *$ & & & \\
\hline Rho4 & -0.191 & 0.090 & $-0.49 * * *$ & & \\
\hline Rho5 & -0.120 & -0.079 & $-0.347 * *$ & $0.50 * * *$ & \\
\hline Predicted probability & 0.41 & 0.385 & 0.651 & 0.536 & 0.235 \\
\hline Joint probability(success) & & & & 0.00112 & \\
\hline Joint probability(failure) & & & & 0.00456 & \\
\hline Number of observations & & & 140 & & \\
\hline Number of simulations & & & 5 & & \\
\hline Log likelihood & & & -285.67 & & \\
\hline Wald $\chi^{2}(65)$ & & & 137.84 & & \\
\hline Prob $>\mathrm{chi}^{2}$ & & & & & \\
\hline $\begin{array}{l}\text { Likelihood ratio test of Rhoij }= \\
0 . \chi^{2}(10)\end{array}$ & & & 51.232 & & \\
\hline $\mathrm{P}>\chi^{2}(10)$ & & & 0.0000 & & \\
\hline
\end{tabular}

Note: "Coef" and "Std. Err" represents coefficient and standard error respectively. “***”, “**”\&"*” represents $1 \%, 5 \%$ and $10 \%$ level of significance, respectively.

Source: own computation from survey result $(\mathrm{N}=140)$.

Ownership of transport facilities: Influenced the choice of wholesalers outlets positively and the choice of collectors' outlet negatively at 5\% and $10 \%$ level of significance respectively. Farmers having own transport facilities are more likely to choose wholesalers market outlets and less likely to choose collectors market outlet. This might be due to the reason that, farmers who have transport facility could supply their product to urban center and sale to wholesalers directly by getting better price, which might go to the collectors. This shows that the availability of transportation facilities helps to reduce long market distance constraints, offering greater depth in marketing choices. This result is in line with that of Fikru et al. (2017) who found that owning transport facilities influenced the choice of collector's outlet negatively and significantly.

Extension contact: The result indicates frequency of extension visit to the households has negative and significant impact on use of retailer's market outlet at $10 \%$ level of significance. This means that frequent extension contact decrease the likelihood of selling kocho to retailers' market outlets. Access to extension service increased the ability of farmers to acquire important market information as well as other related agricultural information that in turn increases farmers' ability to choose the best market outlets for their product. This is in line with Abraham (2013) who found negative impact of agricultural extension service on the probability of choosing collector and retailer outlets compared to wholesale outlet in vegetable market outlet choice.

Kocho quantity supplied to market: The likelihood of choosing wholesalers market outlet was positively and significantly affected by quantity of Kocho sold and negatively affected consumer market outlets at $1 \%$ and $5 \%$ level of significance. This means that large quantity of kocho supplied to market increases the likelihood of selling kocho to wholesaler's market outlets but decrease the likelihood of selling kocho to consumer market outlets. Kocho producer with large amount prefer wholesalers market outlets but producer with small amount prefer consumer market outlets. The result is consistent with Nuri (2016) who indicated that large quantity of Kocho increases the likelihood of selling Kocho to wholesalers outlets. Kassa et al. (2017) also reported that the likelihood of choosing consumer was negatively and significantly affected by honey quantity sold. This might be related to the fact that wholesalers buy in large volume relative to other market channels for making proper benefit. However, consumer need small amount for consumption.

Post-harvest value addition: It has a significant and positive relationship with the likelihood of choosing consumer and processors market outlets at $1 \%$ and $10 \%$ significant level and a significant negative relationship with the likelihood of choosing collectors and retailers market outlet at $1 \%$ and $10 \%$ significant level. This result shows that Kocho producers who add value would more likely to choose consumer and processors market outlets. This result is consistent with the findings of Abraham (2013) that showed that post-harvest handling is negatively and significantly related with collector market outlet. Post-harvest value addition practice will increase the probability of households ${ }^{e e}$ decision to sell Kocho to consumer and processors marketing channels and will decrease the probability of householdse to choose collector and retailers outlet. The reason may be selling to consumer and processors market outlet requires transporting the product to urban centers, who seek better quality and farmers secure better price than collector's market outlet.

Perception of farmers towards current price of Kocho: It has a positive and significant effect on households choice of wholesaler's market outlets at 5\% significant level. If the Kocho producers perceive better price of kocho when making selling decisions, then Kocho producers are more likely to choose wholesalers market outlets. This is consistent with Nuri (2016) who showed that Perception of farmers towards current price of Kocho has positive and significant effect on households to choose wholesalers market outlet. The possible reason might be when the 
farmer perceive better price they would supply more which can be absorbed by wholesalers.

\section{CONCLUSIONS AND RECOMMENDATIONS}

Based on the findings of this study, the following recommendations (policy implications) are found to be relevant to improve Kocho production and marketing system in the study area.

The finding of the study identified that amount of value addition and quantity of Kocho supplied is important factors observed to influence choice of appropriate market outlets. Accordingly, when farmers add value, the quality and or the demand for that product will increase which will in turn increase their probability of choosing appropriate market outlets. Value addition enhances the choice of appropriate market outlets so that focuses have to be considered with value addition of Enset products and increasing the quantity of Kocho produced.

Own transport facility and distance from the nearest market are other important factor that influence the choice of suitable market channels. Therefore, government has to build more rural road infrastructure. Extension service has a significant role in increasing the choices of pertinent market channel. Therefore, extension workers have to provide adequate information, education and training for farmers on how to add value and select pertinent market outlet.

\section{REFERENCES}

Abebe U and Paul, J (2015). Enset value chain analysis; The case of Dire Enchini woreda, Oromia regional state, Ethiopia. Journal of Research in Computer Application and Management, 3(2): 7-14.

Abraham T (2013). Value chain analysis of vegetables: The case of Habro and Kombolcha Woredas in Oromia region. MSc Thesis, Haramaya University, Ethiopia.

Abrham S, Yishak G and Melese T (2012). Diversity, Challenges and Potentials of Enset (Ensete ventricosum) Production: In Case of Offa Woreda, Wolaita Zone, Southern Ethiopia. Food Science and Quality Management ISSN 2224-6088 (Paper). ISSN 2225-0557 (Online) Volume 7, 2012.

Ashenafi C, Tadesse K, and Girma G (2017). Value chain analysis of warqe food Products in Ethiopia. International Journal of Managing Value and Supply Chains, 8(1).

Belderbos R., M. Carree, B. Diederen, B. Lokshin, and R. Veugelers, (2004). Heterogeneity in research and development cooperation strategies. International Journal of Industrial Organization, 22: 1237-1263.

Berhanu K, Derek, B., Kindie G and Belay K (2013). Factors affecting milk market outlet choices in Wolaita Zone, Ethiopia. African Journal of Agricultural Research, 8(21).

Berhanu K (2012). Market access and value chain analysis of dairy industry in Ethiopia: The Case of Wolaita zone. PhD Dissertation, Haramaya University, Haramaya, Ethiopia.

Bezuneh, T (2012). Technological Challenges of Sustainable Enset Farming System: For Enhancing the Production of Food/Fibre and Industrial Outputs. Enset Research and Development Experience in Ethiopia. Proceeding from Enset National Workshop held in Wolkite, Ethiopia, 19-20.

CDOANR (Cheha District Office of Agriculture and Natural Resource) (2017). Annual Report of the district Agricultural and natural resource office. Cheha, Gurage Zone, Ethiopia.

CSA (Central Statistical Agency). 2017. Agricultural Sample Survey 2016/2017 (2009 E.C.) Volume I, 584 Statistical Bulletin, Report on Area and Production of Major Crops private Peasant Holdings, Meher Season, viewed 26 january 2018, < http://www.csa.gov.et/images/general/news/areaandproduc-tion.

Fikru T, Efa G, Hailu M (2017). Analysis of Sesame Marketing Chain in Case of Gimbi Districts, Ethiopia. Journal of Education and Practice. ISSN 2222-1735 (Paper) ISSN 2222-288X (Online) 8(10).

Jema H (2008). An Economic Efficiency and Marketing Performance of Vegetables in Eastern and Central part of Ethiopia Doctorial thesis, Nov., 2008, Sweden.

Kassa T, Jema H and Bosena T (2017). Determinants of honey producer market outlet choice in Chena District, southern Ethiopia: a multivariate probit regression analysis. Journal of Agricultural and Food Economics. doi 10.1186/s40100-017-0090.

Masten, S. and S. Saussier (2002). "Econometrics of Contracts," an assessment of developments in the empirical literature on contracting. UK, Cambridge Univ. Press, Cambridge.

Nuri L (2016). Value chain analysis of Enset (Enset ventricosum) in Hadiya zone. Doctoral Dissertation, Haramaya University, Haramaya, Ethiopia.

Shigeta, M (1991). The ethno botanical study of Enset (Enset ventricosum) in Southwestern Ethiopia. Doctral Dissertation, Center for African area studies, Kyoto University, Japan.

Steven A. Brandt, Anita Spring, Clifton Hiebsch, J. Terrence McCabe, Endale Tabogie, Mulugeta Diro, Gizachew Wolde-Michael, Gebre Yntiso, Masayoshi Shigeta, and Shiferaw Tesfaye (1997). Tree against hunger, Ensetbased agricultural systems in Ethiopia. Kyoto University Center for African Area Studies and University of Florida. USA.

Tesfaye A (2013). Determinants of crop diversity and composition in Enset-coffee agro forestry home gardens of Southern Ethiopia. MSc Thesis, Hawassa University, Ethiopia. 
Tsedale W (2009). Globalization and neo-liberalization: challenge and opportunities to Enset crop-based agricultural communities and their farming system in Ethiopia. Doctoral Dissertation, University of Alberta, Canada.

Wolday A and Eleni G/m (2003). An analysis of the Structure, Conduct, and Performance of the Ethiopian Grain Market, Addis Ababa.

World Bank. (2013). Agri-Business in Africa: Removing Barriers to Regional Trade to Food Staples. Washington, DC. 